Г. І. РУдько, д-р геол.-мінерал. наук, д-р геогр. наук, д-р техн.наук, професор, голова Державної комісії України по запасах корисних копалин, office@dkz.gov.ua, https://orcid.org/0000-0001-7752-4310, О. В. НЕЦЬКИЙ, начальник управління нерудних корисних копалин, підземних вод та інформаційних технологій у геології (Державна комісія України по запасах корисних копалин), office@dkz.gov.ua, https://orcid.org/0000-0002-7451-8924, С. Ф. ЛИТВИНюК, канд. геол. наук, начальник управління горючих та рудних корисних копалин (Державна комісія України по запасах корисних копалин), office@dkz.gov.ua, https://orcid.org/0000-0003-3763-2100
H. RUDKO, Dr. Sci. (Geol. \& Mineral.), Dr. Sci. (Geogr.), Dr. Sci. (Engin.), Professor, Chairman of the State Commission of Ukraine on Mineral Resources, office@dkz.gov.ua, https://orcid.org/0000-0001-7752-4310, O. NETSKYI, Head of Department (State Commission of Ukraine on Mineral Resources), office@dkz.gov.ua, https://orcid.org/0000-0002-7451-8924, S. LYTVYNIUK, PhD (Geol.), Head of Department (State Commission of Ukraine on Mineral Resources), office@dkz.gov.ua, https://orcid.org/0000-0003-3763-2100

\title{
НАУКОВО-МЕТОДИЧНІ I НОРМАТИВНІ ЧИННИКИ АКТУАЛІЗАЦІЇ РЕЗУЛЬТАТІВ ГЕОЛОГО-ЕКОНОМІЧНИХ ОЦІНОК РОДОВИЩ КОРИСНИХ КОПАЛИН
}

\section{SCIENTIFIC-METHODICAL AND REGULATORY FACTORS UPDATES OF THE RESULTS OF GEOLOGICAL AND ECONOMIC EVALUATIONS OF MINERAL DEPOSITS}

Розглянуто основні аспекти актуалізації результатів геолого-економічних оцінок родовищ корисних копалин, науково-методичні й нормативні чинники проведення цієї роботи, спрямованої на підвищення рівня інформаційної вивченості родовищ корисних копалин як основи Державного балансу запасів корисних копалин України, системи управління ресурсами й запасами корисних копалин, інвестиційного планування. Принцип періодичності проведення геолого-економічної оцінки відповідає міжнародним практикам щорічного розкриття звітності про запаси і ресурси корисних копалин перед фондовими біржами.

Загалом проведення періодичних (повторних) геолого-економічних оцінок актуалізує техніко-економічні й фінансові показники господарської діяльності користувачів надр для цілей інвестиційного планування та оподаткування.

Втрати держави внаслідок послаблення контролю за станом запасів корисних копалин і раціональним використання надр сукупно важко оцінити, проте вони однозначно вагомі й значущі.

Ключові слова: геолого-економічна оцінка, ділянка надр, родовище, кондиції, мінеральна сировина.

Primary aspects of updating the results of geological and economic assessments of mineral deposits, scientific-methodological and regulatory factors of this work aimed at increasing the level of informational study of mineral deposits as the foundation of the State Balance of Mineral Reserves of Ukraine, mineral reserves and resource management system, investment planning have been considered. The principle of periodicity of GEA is in line with international practices on the annual disclosure of reports on mineral reserves and resources for stock exchanges.

The cost of the GEA materials expertise is, on average, much lower than the annual profits of mining enterprises, and incomparably lower than the enterprises' profit for the entire period of deposit development. Mining companies that have violated the deadline for regular repetitive geological and economic assessment of mineral reserves of the subsoil area, calculate tax liabilities using a profitability ratio equal to triple discount rate of the National Bank of Ukraine.

In Ukraine, the legislation is being changed in order to adapt to European standards and best international practices, which will contribute to technological and economic transformation, and it will affect requirements of standards for product quality, which should ensure its competitiveness In such circumstances, the issue of periodicity of geological and economic assessment and the development of methodological foundation for its implementation becomes crucial, as changes in the abovementioned indicators are reflected in the conditions for reserve calculation, quantity and commercial significance of reserves, mining enterprise profitability and profitability of activities associated with mineral extraction, in particular The norm on repeated state expertise and assessment of mineral reserves every five years of subsoil use, abolished in 2017, has updated technical, economic and financial indicators of economic activity of subsoil users for investment planning and taxation.

State's losses due to the weakening of control over reserves and rational use of subsoil are difficult to assess, but they are clearly huge and significant. About 80 per cent out of the total number of mineral deposits and manifestations have not yet been considered by the State Commission of Ukraine on Mineral Resources in accordance with the conditions of the modern scientific and methodological base.

Keywords: geological and economic assessment, subsoil area, deposit, condition, mineral raw materials.

Вступ. Періодичний аналіз результатів геологічного та техніко-економічного вивчення запасів і ресурсів корисних копалин у межах ділянок надр (родовищ) 3 метою встановлення та/або зміни промислового значення на підставі інформації про фактичні технологічні схеми, техніко-економічні показники та фінансові результати видобування корисних копалин у межах такого об'єкта надрокористування ототожнюють з геолого-економічною оцінкою.
Економічні та технологічні чинники, що враховуються під час визначення балансової належності запасів і промислового значення родовища у зв'язку з розвитком і застосуванням нових технологій, збільшенням обсягів видобування, глибини переробки корисних копалин, постійно змінюються. Також втрачає актуальність інформація про об’єкт надрокористування (родовище) і в разі тривалого незалучення родовища із затвердженими запасами до промислової експлуатації (проблема так званих сплячих ліцензій); подекуди втрачається і первинна геологічна інформація щодо розвідки родовища. 
Залежно від зміни ступеня знань про об'єкт надрокористування, уявлень про природно-технологічні чинники моделі ділянки надр (родовище), розвитку науково-методичних підходів, що обгрунтовують такі чинники, а також фінансових, нормативних, екологічних, соціальних та інших вимог, які визначають умови й доцільність використання та експлуатації ділянки надр (родовища) в часі, особливої актуальності набуває питання періодичності проведення геолого-економічних оцінок.

Втрати держави через відсутність інформації про стан запасів корисних копалин, напрями їхнього використання і повноту видобування важко оцінити сукупно. Проте вони вагомі й значущі, а в комплексі зумовлюють появу проблем, як-от нераціональне використання надр, послаблення державного управління ними, неактуальність Державного балансу запасів корисних копалин України, складнощі під час обгрунтування об'єктів надрокористування, щодо яких відбувається підготовка надання спеціальних дозволів на користування надрами через процедуру аукціонів.

Виклад основного матеріалу. Відповідно до Положення про Державну комісію України по запасах корисних копалин (далі - ДК3), затвердженого постановою Кабінету Міністрів України від 10.11.2000 № 1689 [8], ДК3 є установою, що діє при Державній службі геології та надр України і провадить науково-технічну діяльність, пов'язану з проведенням на замовлення користувачів надр або за дорученням відповідних центральних органів виконавчої влади державної експертизи геологічних матеріалів з вивчення і використання надр та оцінки запасів корисних копалин.

Головними завданнями ДКЗ є: встановлення кондицій на мінеральну сировину для обчислення запасів корисних копалин у надрах; прийняття рішень щодо кількості, якості та ступеня вивченості запасів розвіданих родовищ корисних копалин і стану підготовленості їх до промислового освоєння.

Згідно з Положенням про порядок проведення державної експертизи та оцінки запасів корисних копалин (затверджене постановою КМУ від 22.12.1994 № 865 [9], далі - Положення № 865) рішення ДК3 оформляються протоколами, що приймаються на пленарних засіданнях і спрямовуються на реалізацію єдиної науково-технічної політики щодо проведення геолого-економічної оцінки (далі - ГЕО). Об'єктами експертизи можуть бути матеріали детальної, попередньої або початкової оцінки запасів і ресурсів корисних копалин; матеріали техніко-економічного обгрунтування кондицій на мінеральну сировину; матеріали техніко-економічного обгрунтування коефіцієнтів видобутку нафти, газу та конденсату; проєкти промислового освоєння родовищ, реконструкції або ліквідації робочих гірничодобувних і збагачувальних підприємств; матеріали техніко-економічного обгрунтування доцільності дальшої розвідки, розробки або списання з державного обліку запасів корисних копалин тощо. ДКЗ систематично проводить аналіз державного балансу запасів корисних копалин і надає рекомендації для користувачів надр щодо подання на повторну або первинну державну експертизу матеріалів геолого-економічної оцінки родовищ корисних копалин (пункт 26 Положення № 865) [9]. У разі потреби ДК3 рекомендує проведення робіт 3 перегляду кондиції на мінеральну сировину для обчислення запасів корисних копалин у межах окремої геолого-економічної оцінки.

Геолого-економічна оцінка - одна з вимог геологічного вивчення надр (стаття 38 Кодексу України “Про надра" [4]).
Результат ГЕО - основа Державного балансу запасів корисних копалин України, Державного кадастру родовищ і проявів корисних копалин.

ГЕО - періодичний аналіз результатів кожної стадії геологічного та техніко-економічного вивчення ресурсів корисних копалин ділянки надр з метою встановлення та/або зміни промислового значення їхніх запасів на підставі інформації про фактичні технологічні схеми, техніко-економічні показники й фінансові результати видобування корисних копалин у межах такої ділянки.

Принцип періодичності проведення ГЕО відповідає міжнародним практикам щорічного розкриття звітності про запаси й ресурси корисних копалин перед фондовими біржами. У процесі виконання міжнародних зобов'язань України, у зв'язку з імплементацію актів законодавства Європейського Союзу, Україна приєдналася до Ініціативи щодо забезпечення прозорості у добувних галузях [2], згідно 3 якою щорічно формуються звіти з відомостями про стан запасів корисних копалин.

Положення № 865 передбачає проведення повторної ГЕО в разі перегляду вимог стандартів щодо кількості або якості корисних копалин, технології їхньої переробки, що зумовлює зменшення сумарних розвіданих запасів більш як на 20 \% або зростання їхнього обсягу більш як на 50 \%. Запаси розроблюваних родовищ підлягають повторній експертизі й оцінці, якщо внаслідок гірничодобувних або додаткових геологорозвідувальних робіт сумарні розвідані запаси зростають більш як на 50 \%, порівнюючи з раніше оціненими ДКЗ, або якщо списані й передбачені для списання розвідані запаси як такі, що не підтвердилися чи недоцільні для видобутку за техніко-економічними умовами родовищ, перевищують нормативи, встановлені законодавством.

ДКЗ проводить державну експертизу й оцінку запасів корисних копалин за результатами розгляду матеріалів ГЕО, які подають користувачі надр.

Положення № 865 у редакції постанови КМУ від 26.03.2008 № 264 містило норму про проведення повторної державної експертизи та оцінки запасів родовищ корисних копалин через що п’ять років експлуатації ділянки надр. Постановою КМУ від 17.12.2017 № 1108 внесено зміни, які цю норму скасовують.

Розгляд матеріалів повторної ГЕО засвідчує, що переважна їхня частина стосувалася родовищ (ділянок надр), які були розвідані багато років тому - в 1950-1997 роках. Деякі з них розробляють з початку XX століття, розвідуючи (дорозвідуючи) неодноразово. Раніше запаси всіх таких родовищ періодично переглядали в ДКЗ СРСР, УкрТКЗ або ДКЗ. На багатьох родовищах (переважно сировини місцевого значення - пісок, суглинки, крейда тощо) запаси в установленому порядку ніколи не затверджували, а розглядали на спільних технічних радах профільних інститутів і геологорозвідувальних організацій. За результатами такого “розгляду” запаси обліковував Державний баланс запасів корисних копалин України, хоча вірогідність їхніх кількісних, якісних та економічних характеристик є низькою й не підтверджується результатами експлуатаціі.

Останнє п'ятиріччя під час проведення повторної ГЕО родовищ твердих корисних копалин постійно простежувалися такі аспекти геолого-економічної вивченості й надрокористування:

- невідповідність результатів розвідки (встановлених кондицій) і результатів розробки родовища - часткове непідтвердження запасів; 
- перекваліфікація балансових (добувних) запасів у недобувні таксони Класифікації запасів і ресурсів корисних копалин державного фонду надр [3] (затверджена постановою КМУ від 05.05.1997 № 432) - позабалансові, умовно балансові, запаси з невизначеним промисловим значенням;

- невідповідність мети спеціального дозволу на користування надрами фактичній діяльності надрокористувачів;

- видобування корисних копалин за межами спеціальних дозволів на користування надрами й гірничих відводів;

- видобування без огляду на контур, визначений спеціальним дозволом на користування надрами, оскільки на початку запровадження процедури ліцензування спеціальні дозволи (ліцензіі) не містили координат ділянок надр, або координати визначались однією точкою;

- реалізація порід розкриву без їхнього геологічного довивчення й затвердження як запасів корисних копалин;

- невідповідність кількості залишку запасів, яка обліковується в Державному балансі запасів корисних копалин України, його фактичній наявній кількості на родовищі, що зумовлено багатьма причинами (неправильний облік, незадокументований видобуток);

- недовивчення корисних копалин, зокрема, в частині проведення їхньої радіаційно-гігієнічної оцінки (до 1986 р. це питання гостро не стояло), що визначає сферу використання корисної копалини і готової продукції, а також невиконання рекомендацій ДКЗ щодо геологічного довивчення корисних копалин, раціонального та ефективного використання надр;

- недостатня вивченість екологічних наслідків видобування корисних копалин (осушення водоносних горизонтів, запилення, небезпечні інженерно-геологічні процеси тощо);

- невідповідність проєкту розробки родовища умовам залягання корисної копалини й сучасним нормам технологічного проєктування, що зумовлює втрати корисної копалини, знижує екологічну безпеку добувних робіт.

3-поміж іншого, потребу проведення повторної геолого-економічної оцінки експлуатаційних запасів питних підземних вод ділянок (родовищ) зумовлює:

1) перегляд вимог до якості питних підземних вод - затвердження ДСанПіН 2.2.4-171-10 “Гігієнічні вимоги до води питної, призначеної для споживання людиною” [1], що регламентує вимоги до якості питних підземних вод і має набагато ширший перелік показників проти тих, що нормувалися під час оцінки запасів підземних вод ДКЗ СРСР (УкрТКЗ);

2) нераціональне використання ресурсів: вибирається набагато менша кількість експлуатаційних запасів (переважно на рівні від перших одиниць до 50-60\%, в окремих поодиноких випадках до 80 \%), ніж надана в користування відповідно до спеціальних дозволів на користування надрами, що зумовлює некоректне врахування обсягів експлуатаційних запасів родовищ питних підземних вод, які перебувають або можуть перебувати у взаємодіі, під час підрахунку їніх експлуатаційних запасів;

3) поява нової Класифікації запасів і ресурсів корисних копалин державного фонду надр [5], що встановлює вимоги до балансових експлуатаційних запасів питних підземних вод, які містять економічний зміст (запаси корисних копалин ділянки надр, для яких на момент проведення геолого-економічної оцінки згідно з техніко-економічними розрахунками та/або матеріалами фінансової звітності підтверджено, що коефіцієнт рентабельності продукції гірничо-добувного підприємства (розрахунковий та/або фактичний) є достатнім для економічно ефективного видобування корисних копалин на такій ділянці надр);

4) неможливість у сучасних умовах оцінити балансові / розвідані запаси підземних вод, а відповідно визначити розмір та причини їхньої зміни, зокрема через те, що термінологічно визначення категорій (балансові / розвідані експлуатаційні запаси підземних вод) відрізняється від цих самих категорій, що використовувалися під час оцінки ДКЗ СРСР (УкрТК3): а) нині розвідані запаси - запаси на базі яких проведена детальна ГЕО їхньго промислового освоєння (тобто і техніко-економічна оцінка); б) балансові запаси запаси, які на момент оцінки згідно з техніко-економічними розрахунками можна економічно ефективно видобути й використати за сучасної техніки й технології видобування та водопідготовки, що забезпечують дотримання вимог раціонального, комплексного використання ресурсів й охорони навколишнього природного середовища;

5) сучасний стан експлуатаційних запасів родовищ (їхніх ділянок), розвіданих понад 30-60 років тому, їхні водогосподарські, санітарні умови, екологічні чинники, що впливають на кількість, якість, напрям або ефективність використання підземних вод, залишаються невідомими (недослідженими в сучасних умовах).

Загалом проведення періодичних (повторних) геологоекономічних оцінок актуалізує техніко-економічні та фінансові показники господарської діяльності користувачів надр для цілей інвестиційного планування та оподаткування.

Щодо зазначених вище питань ДКЗ ухвалює відповідні рішення про статус запасів у межах ділянки надр і надає рекомендації користувачам надр.

Вартість робіт з експертизи матеріалів ГЕО в середньому набагато менша за показники річних прибутків гірничих підприємств і незрівнянно нижча від показників прибутку підприємств за весь період експлуатації родовищ.

За даними ДНВП “Державний інформаційний геологічний фонд України”, наведеними в щорічнику “Мінеральні ресурси України 2020” [5] в надрах України виявлено понад 20 тис. родовищ і проявів зі 117 видів мінеральної сировини, з яких 10390 родовищ (зокрема 1812 ділянок вод підземних питних і технічних, мінеральних) мають промислове значення і враховуються Державним балансом запасів корисних копалин України. Промисловістю освоєно понад 3778 родовищ або менш як 40 \% промислово значущих родовищ.

За період дії Класифікації запасів корисних копалин України, починаючи з 1997 року і дотепер, ДКЗ оформлено близько 4900 протоколів розгляду матеріалів геолого-економічних оцінок запасів як нових родовищ, так і виявлених до набуття чинності Класифікації. Водночас велику частку об'єктів надрокористування розглянуто неодноразово. Із загальної кількості родовищ і проявів корисних копалин близько 80 \% об'єктів ДКЗ ще не розглядала відповідно до умов сучасної науково-методичної бази.

Згідно з Податковим кодексом України [7] розрахункова вартість одиниці виміру товарної продукції гірничого підприємства обчислюється за формулою, що враховує коефіцієнт рентабельності гірничого підприємства. Цей коефіцієнт обчислюється в матеріалах геолого-економічної оцінки запасів корисних копалин ділянки надр, що розглядаються ДКЗ.

Гірничі підприємства, які порушили строк регулярної повторної геолого-економічної оцінки запасів корисних копалин ділянки надр, обчислюють податкові зобов'язання із застосуванням коефіцієнта рентабельності, що дорівнює трикратному розміру облікової ставки Національного банку України. 
В Україні відбуваються зміни законодавства 3 метою його адаптації до Європейських стандартів і найкращих світових практик, що сприятиме технологічним та економічним перетворенням, а також позначиться на вимогах стандартів до якості продукції, що має забезпечити ії конкурентоспроможність. У таких умовах питання періодичності геолого-економічної оцінки й розвитку методичних основ ії проведення набуває вкрай актуального значення, оскільки зміна показників, зазначених вище, впливає на кондиції для підрахунку запасів, кількість і промислове значення запасів, коефіцієнт рентабельності гірничого підприємства й рентабельність діяльності, пов'язаної з видобуванням корисних копалин зокрема.

3 огляду на зазначене вище, констатуємо необхідність регулярного періодичного проведення ГЕО внаслідок появи нових сучасних вимог оцінки запасів родовищ корисних копалин. Ідеться, зокрема, про:

- рішення Уряду України в 1997 р. затвердити нову Класифікацію запасів і ресурсів корисних копалин державного фонду надр, розроблену відповідно до сучасних практик, зокрема міжнародної Рамкової класифікації ООН;

- прийняття сучасних вимог (показників) щодо якості корисних копалин і товарної продукції, які враховуються промисловістю (ДСТУ, ТУ тощо) [6];

- сучасні вимоги щодо техніко-економічних показників, які визначають доцільність проєкту з видобування загалом і вартість запасів у надрах, а також базу оподаткування, що регулюється Податковим кодексом України зокрема;

- загальні вимоги законодавства щодо заборони видобування (обмеженого видобування запасів) у межах лінійних об'єктів (дороги, ЛЕП, продуктопроводи), природоохоронних об'єктів (зони санітарної охорони річок, водозаборів, заповідників тощо); заборони забудови площ залягання запасів корисних копалин і розпаювання земель у їніх межах - зумовлює втрату промислового значення частини (більшої частини, в одиничних випадках родовища загалом) запасів i потребу списання їх в установленому порядку;

- високу ефективність розробки окремих родовищ через пошук і залучення високопродуктивних надрокористувачів;

- зміну методики підрахунку запасів (раніше більшість запасів твердих корисних копалин підраховували в контурі гірничих виробок - “валізою”, як результат - недостовірність обліку балансових (добувних) запасів), що нині виконується в межах контуру, обгрунтованого проєктом розробки родовища.

3 огляду на зазначене вище й унеможливлення неоднозначного трактування положень у законодавчому й нормативно-методичному полі треба законодавчо передбачити, що:

a) техніко-економічні розрахунки постійних кондицій на мінеральну сировину ділянки надр для визначення економічно ефективного видобування корисних копалин щодо розподілу економічної вигоди між користувачем ділянки надр та Державою користувач ділянки надр має розробляти з періодичністю що п’ять років і подавати до ДКЗ на перегляд (повторне затвердження);

б) повторна Державна експертиза матеріалів геологоекономічної оцінки запасів родовищ корисних копалин загальнодержавного значення складної будови, для яких якісні й кількісні параметри корисної копалини не витримані в плані чи розрізі, має проводитися з періодичністю не більш як що п'ять чи що сім років, а також у разі:

- отримання нових даних під час підготовки до видобування, видобування або перегляду вимог стандартів щодо кількості або якості корисних копалин, технології їхнього видобутку та переробки, складання або коригування робочих проєктів, додаткових геологорозвідувальних робіт, що змінюють сумарні балансові запаси більш як на 20 \% у межах блока, який забезпечує видобування із затвердженою проєктною потужністю впродовж п'яти років;

- перевищення строку затвердження запасів (для підземних вод);

- залучення до експлуатації нерозроблюваних родовищ, якщо з моменту останнього розгляду запасів ДКЗ минуло понад десять років;

- якщо розвідані запаси, списані як непідтверджені чи недоцільні для видобутку за техніко-економічними умовами родовищ, упродовж трьох років поспіль перевищують нормативи, затверджені ДКЗ або встановлені законодавством;

- змінення вартості сировини, тарифів, податків і ставок або цін чи номенклатури товарної продукції, що суттєво (сума, тотожна або більша за $10 \%$, може вважатися суттєвою, якщо немає даних або переконливої аргументації проти; сума, тотожна або менша за 5 \% може вважатися несуттєвою, якщо немає даних або переконливої аргументації проти) змінює дохід власника надр або сумарні балансові запаси в межах ділянки, що за обсягом запасів забезпечує видобуток із затвердженою проєктною потужністю протягом п'яти років.

За період з 2018 по 2020 роки, коли законодавчу норму, що передбачала періодичне проведення обов'язкової повторної геолого-економічної оцінки що п'ять років, було скасовано, кількість запитів на державну експертизу запасів істотно скоротилася. Зокрема, у 2017 р. ДКЗ було оформлено 454 рішення колегії ДКЗ, у 2020 р. - 230, а за І півріччя 2021 року укладено тільки 82 угоди на проведення експертизи матеріалів геолого-економічної оцінки.

Висновки. Проведення ДКЗ державної експертизи та оцінки запасів корисних копалин за результатами періодичного розгляду матеріалів повторної геолого-економічної оцінки родовищ корисних копалин тотожне оцінкам із застосуванням комерційних класифікацій, що використовуються у світовій практиці й зумовлюють однозначно високу якість проведеної експертизи.

Відсутність періодичних геолого-економічних оцінок родовищ корисних копалин унеможливлює управління міне-

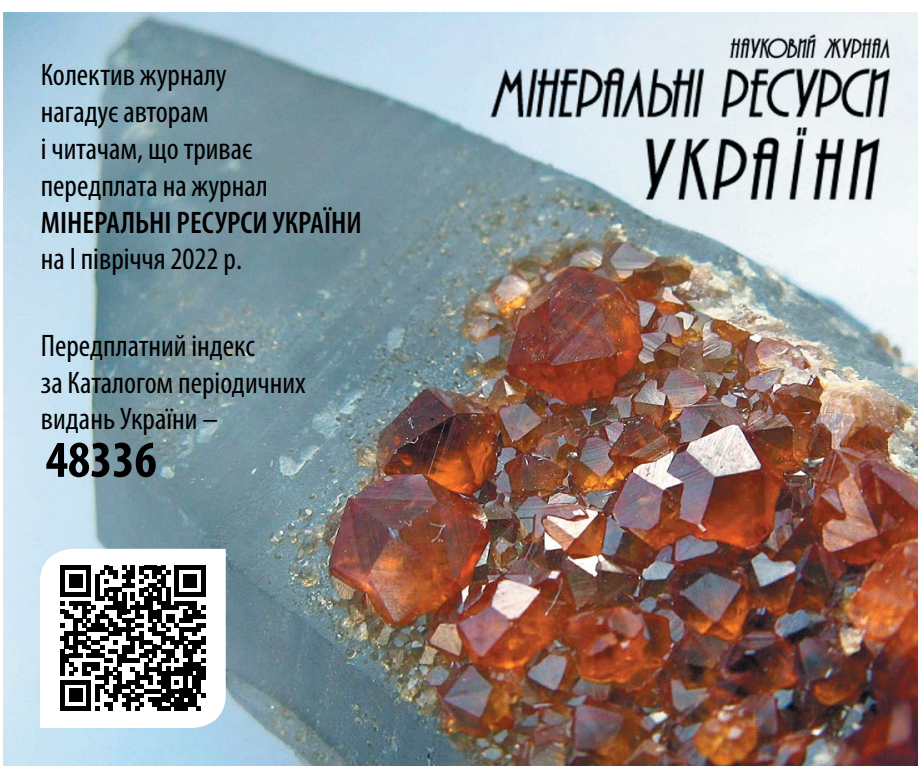


рально-сировинною базою України [10] і досягнення Цілей сталого розвитку на національному рівні.

За період існування ДКЗ не було жодної скарги з боку користувачів надр щодо виконаних геолого-економічних досліджень і жодного непідтвердження запасів корисних копалин, що свідчить про винятково високу якість виконання робіт. Експерти ДК3 - фахівці високої кваліфікації, з тривалим досвідом робіт у геологічній галузі та бездоганною репутацією.

\section{ЛІТЕРАТУРА}

1. ДСанПіН 2.2.4-171-10 "Гігієнічні вимоги до води питної, призначеної для споживання людиною”//Офіційний вісник України. 2010. - № 51. - 99 c.

2. Закон України. Про забезпечення прозорості у видобувних галузях//Офіційний вісник України. - 2018. - № 82. - 8 с.

3. Класифікація запасів і ресурсів корисних копалин державного фонду надр//Офіційний вісник України. - 1997. - № 19. - 104 с.

4. Кодекс України "Про надра"//Відомості Верховної Ради України. - 1994. - № 36. - 340 с.

5. Мінеральні ресурси України. - Київ: Державне науково-виробниче підприемство "Державний інформаційний геологічний фонд України,"2020. - 270 с.

6. Наказ від 07.12.2005 №300 “Про затвердження Положення про порядок розробки та обгрунтування кондицій на мінеральну сировину для підрахунку запасів твердих корисних копалин у надрах"// Офіційний вісник України. - 2006. - № 5. - 137 с.

7. Податковий кодекс України//Відомості Верховної Ради України. -2011 . - № 13-14, № 15-16, № 17. - 556 с.

8. Про затвердження Положення про Державну комісію України по запасах корисних копалин//Офіційний вісник України. - 2000. - № 46. - 194 c.

9. Постанова Кабінету Міністрів України від 22 грудня 1994 р. № 865 “Про затвердження Положення про порядок проведення державної експертизи та оцінки запасів корисних копалин”//Зібрання постанов Уряду України. - 1995. - № 3. - 55 с.

10. Рудько Г. І., Ловинюков В. І., Литвинюк С. Ф., Нецький О. В. Управління ресурсами корисних копалин на основі рамкової класифікації ООН (національна класифікація запасів і ресурсів корисних копалин України)//Розвідка та розробка нафтових і газових родовищ. - 2019. - № 4 (73). - С. 7-15.

\section{REFERENCES}

1. DSanPiN 2.2.4-171-10 "State sanitary standard. Hygienic requirements for drinking water intended for human consumption"//Ofitsiinyi visnyk Ukrainy. - 2010. - № 51. - 99 p. (In Ukrainian).

2. Law of Ukraine. On ensuring transparency in the extractive industries//Ofitsiinyi visnyk Ukrainy. - 2018. - № 82. - 8 p. (In Ukrainian)

3. Classification of reserves and resources of minerals of the state subsoil fund//Ofitsiinyi visnyk Ukrainy. - 1997. - № 19. - 104 p. (In Ukrainian)

4. Code of Ukraine about subsoil//Vidomosti Verkhovnoi Rady Ukrainy. - 1994. - № 36. - 340 p. (In Ukrainian).

5. Mineral resources of Ukraine. - Kyiv: Derzhavne naukovo-vyrobnyche pidpryiemstvo "Derzhavnyi informatsiinyi heolohichnyi fond Ukrainy”,2020. - 270 p. (In Ukrainian).

6. "On approval of the Regulations on the procedure for the development and justification of conditions for mineral raw materials for the calculation of reserves of solid minerals in the subsoil"//Ofitsiinyi visnyk Ukrainy. - 2006. - № 5. - 137 p. (In Ukrainian).

7. Tax Code of Ukraine//Vidomosti Verkhovnoi Rady Ukrainy. 2011. - № 13-14, № 15-16, № 17. - 556 p. (In Ukrainian).

8. On approval of the Regulations on the State Commission of Ukraine for Mineral Resources//Ofitsiinyi visnyk Ukrainy. - 2000. № 46. - 194 p. (In Ukrainian).

9. "On approval of the Regulations on the procedure for conducting state examination and assessment of mineral reserves"//Zibrannia postanov Uriadu Ukrainy. - 1995. - № 3. - 55 p. (In Ukrainian).

10. Rudko H. I., Lovyniukov V. I., Lytvyniuk S. F., Netskyi O. V. Management of mineral resources on the basis of the UN framework classification (national classification of reserves and resources of minerals of Ukraine)//Rozvidka ta rozrobka naftovykh i hazovykh rodovyshch. - 2019. - № 4 (73). - P. 7-15. (In Ukrainian).

Рукопис отримано 17.12.2021.

\section{MHIFPPIABHII PECYPCH YKPPIIIII}

Редакція приймає оригінальні, раніше не опубліковані статті геологічної, геолого-мінералогічної та технічної тематик.

Статті треба надсилати в друкованому (два примірники) й електронному вигляді, бажано українською мовою.

Обсяг однієї наукової статті - до 25 стор. машинопису через 2 інтервали (разом з табл., фото, рис. та підписами до них, бібліографічним списком, анотацією), оглядової - 6-7 стор., інформаційного повідомлення - 3-4 стор.

До рукопису потрібно додати акт експертизи й такі відомості про автора/авторів: прізвище, ім'я та по батькові (повністю); учене звання й учений ступінь; посада чи професія; місце роботи (назва установи чи організації); адреса місця роботи, номер телефону; адреса місця проживання, номер телефону, електронна адреса, ORCID.

До кожної статті обов'язково навести: індекс УДК, анотацію (українською та англійською), бібліографічний список за алфавітом (оформлений відповідно до сучасних вимог), рисунки, таблиці та підписи до них (окремі файли).

Комп'ютерні макети рисунків приймаються в разі дотримання таких умов:

Рисунки подаються окремими файлами, їх не потрібно розміщувати у файлі документу MS Word.

Р а с т р о в а графіка: чорно-біле зображення - *.tif чи *.psd (Adobe PhotoShop); повнокольорове зображення - *.tif, *.eps, *.psd-формат, роздільна здатність 300 dpi. Кольорова модель CMYK, чорний колір в одному каналі.

В е к т о р н а графіка: файли формату *.ai, *.eps (Adobe Illustrator) чи *.cdr (CorelDraw). Використані шрифти мають бути подані окремо або переведені в криві. Растрову графіку до векторного макета не вносити.

- Редколегія може не поділяти думок автора.

- Автори відповідають за точність викладених фактів, даних, цитат, бібліографічних довідок, написання географічних назв, власних імен, геологічних термінів тощо.

Рішення про публікацію статті в журналі приймається на основі незалежної експертизи, яку організовує редакція журналу.

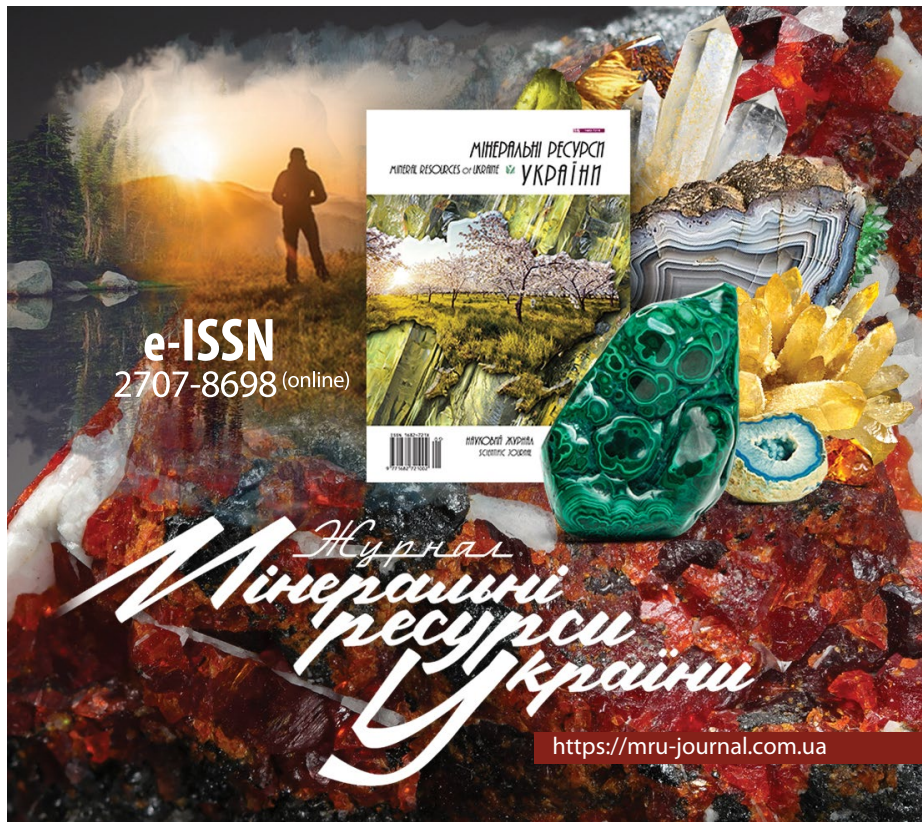

